\title{
Building a Movement: Betty Friedan and The Feminine Mystique
}

\author{
Jean Calterone Williams
}

Judith Hennessee, Betty Friedan: Her Life. New York: Random House, 1999.

Daniel Horowitz, Betty Friedan and the Making of "The Feminine Mystique": The American Left, the Cold War, and Modern Feminism. Boston: University of Massachusetts Press, 1998.

$\mathrm{R}$ complex look at feminism and the ways that Betty Friedan shaped the movement's trajectory in the 1960 s and 1970s. Both authors purport to have written Friedan's biography, but there is minimal overlap in the information they present. Though each book helps to make sense of the feminist movement, Hennessee and Horowitz have particular sets of concerns that ultimately make for accounts very different in approach and focus. In the process of writing the story of Friedan's life, Hennessee describes the personalities and political actions central to the development of "second-wave" feminism, including the founding of the National Organization for Women (NOW) and the National Women's Political Caucus (NWPC). She writes as something of an insider, caught up in the 1970 in what she describes as "the most exhilarating time of my life" (xv), crediting Friedan for many of the movement's early successes. Horowitz concentrates less on the movement itself and more on the ideas 
that influenced Friedan, and in turn, second-wave feminism. Arguing that many of the philosophies and movement priorities of second-wave feminism can be traced through Friedan to radical-left politics of the 1930s and 1940s, Horowitz expands our understanding of the intellectual and political precursors to "modern feminism."

Horowitz maintains that Friedan's early commitments to unionism, antifascism, and antiracism shaped her feminist politics. However, Friedan downplayed the links between her radical political sympathies and her feminism, both in The Feminine Mystique and in the organizations she founded. Because she had personally experienced anti-Semitism and seen the devastating effects of McCarthyism, Friedan was acutely aware of the damage to the movement that would come with accusations that feminism was a "Communist conspiracy." Though feminism as a movement should be understood as linked, through Friedan's political goals and her personal connections, to earlier social-justice movements, Horowitz contends that these ties are lost in most historical renderings of second-wave feminism. Indeed, most of the narratives that describe the beginnings of the feminist movement in the 196os and 1970 point to the civil rights and antiwar movements of the same period as the source for many of the political theories and direct-action methods used by feminists, the place where some feminist activists developed their political sensibilities.

Horowitz shows that Friedan's political education followed a different trajectory, providing plenty of examples to support his argument. Beginning with her adolescence and college years, he suggests that Friedan struggled with the anti-Semitism of both her peers and the larger society and with cultural pressures to downplay her intelligence. Growing up in an era when women had limited hopes regarding education and work opportunities gave Friedan insight into women's lives and formed a nascent analysis of women and work that would become the centerpiece of Friedan's feminism. From there, Horowitz chronicles her work as a labor journalist at Federated Press and UE News, her stint at the Highlander Folk School, and her circle of mentors and friends with Popular Front sympathies. Even Friedan's years at Parkway Village, a diverse suburban community in Queens, New York, is perceived by Horowitz to be consistent with Friedan's radical past. She participated in battles over housing issues and racial diversity within the community, leading a call for affordable rent.

It is, however, Friedan's involvement with “women's issues” through her work as a writer for UE News that is particularly important for Horowitz's argument. Horowitz describes the United Electrical, Radio, and Machine Workers of America as "a radical union in the forefront of the fight for social justice for African American and women workers" (121). Friedan was a staff journalist and authored several pamphlets on women and work, further honing her radical political convictions. But her labor journalism also provided an education in the limitations of unionism for women: Friedan claims she lost her job at UE News when she requested a second 
maternity leave. For Horowitz, Friedan's years as a labor journalist bring together the influences that molded The Feminine Mystique: "Her involvement in unions taught her a great deal about the problems women faced. Friedan's commitment to women's rights, her disillusionment with unions, the contradictions of her own class position, her longings to be in the mainstream, and McCarthyism were key factors in her shifting, over time, from Popular Front feminism that focused on working-class women to middle-class suburban feminism" (142). Hennessee does not disagree with this analysis but perceives these influences as less central to Friedan's politics than Horowitz. In fact, Hennessee covers Friedan's life pre-Feminine Mystique in just six chapters, with the remaining twenty-four devoted to Friedan's place in the feminist movement, power struggles within the movement, and the impact of feminist activism on a personal level in Friedan's and others' lives. The UE News experience is important primarily insofar as her firing "became a landmark in the Friedan annals, [with] the first glimmer of her feminism" generated in response to the unfair firing $(52)$.

Hennessee moves from the UE and other early experiences to a lively and detailed consideration of second-wave feminism. Though seminal events are covered, such as the 1970 Women's Strike for Equality and the founding of NOW, Hennessee is most interested in describing and making sense of Friedan's political choices through the lens of the personal. Movement politics are often analyzed in terms of personalities or personal conflicts, especially between Friedan and Gloria Steinem, with the force of Friedan's acerbic and domineering personality a central concern. Indeed, though Hennessee in many ways celebrates Friedan's achievements, calling her "the woman who had changed our lives" (xvi), the picture of Friedan that she develops is one of an egotist who disliked other women, who treated those who worked for her imperiously and even abusively.

Both Friedan's authoritarianism and Hennessee's focus on the personal to explain political choices are exemplified by Friedan's conflict with lesbians in NOW. Concerned that lesbians would tarnish NOW's image as a mainstream, conventional organization, Friedan's discomfort with "the lavender menace" came to a head in 1969 , when she tried to rid the organization of "the lesbians." Hennessee probes what she terms Friedan's "homophobia" for its political ramifications, analyzing second-wave feminism's struggles with issues of sexual identity and the tendency to adopt the homophobia of the larger society. But ultimately Friedan's political choices are explained through "personal attitudes": "She needed to belong; she clung to the mainstream as to a life raft. Being a lesbian was like being an outsider and a Jew. Lesbians were rejects, and if she championed their cause, she would be rejected. . . . Her fear was like the fear of Red-baiting: lesbians would destroy all that she had done, her movement and her life, her achievement and her status, and she would be nothing. In striking at them, she was defending herself” (131). Friedan's fight for 
social justice, then, had its limitations. Indeed, Hennessee shows her to be a visionary with regard to the possibilities for women's activism to change the conditions of their lives, but her vision was limited to a "culturally conservative" view of sexuality and family life.

Both Horowitz's and Hennessee's books are fascinating reads. Horowitz's book, in particular, is intellectual history at its best, rich and varied in its sources and meticulously documented. But in reading his book, I wished for more concrete examples to show how the ideas of Popular Front feminism affected second-wave feminism. Horowitz does an impressive job describing Friedan's early political influences and activities, but spends significantly less time analyzing how they played out in the feminist movement. When he does provide specific examples to link Friedan's earlier politics to The Feminine Mystique and to her post-1950s feminism, his arguments are convincing. For example, he suggests that:

Popular Front feminism - represented by the unionism of the CIO and the probing discussions around the Congress of American Women-deepened and broadened Friedan's commitments. . . . writing for Federated Press and UE News gave Friedan sustained familiarity with issues such as protests over the impact of rising prices on households, the discontent of housewives with domestic work, the history of women in America, the dynamics of sex discrimination, the negative force of male chauvinism, and the possibility that the cultural apparatus of a capitalist society might suppress women's aspirations for better lives. (198)

Later, he examines NOW's original statement of purpose for reflections of Friedan's commitments to social justice developed as a labor journalist. These moments are tantalizing but less well developed and detailed than a reader interested in the particularities of feminist movement politics might like.

On the other hand, Hennessee's focus on personalities and personal conflicts within the movement also means that the political opportunities that made the $1960 \mathrm{~s}$ and 1970 sipe for feminist movement are largely ignored. Similarly, the various mobilizing techniques experimented with by feminist activists, particularly the use of direct action, might be more thoroughly plumbed for their role in shaping the direction of the movement. Because Hennessee focuses on Friedan's personality - the book's main subject is Friedan and not the movement itself — it may appear that the force of Friedan's drive, ego, and intellect were what made political change possible. Friedan's famously domineering and imperious manner might be better contextualized within a clearer description of the era's political climate and opportunities.

These arguments aside, Hennessee's and Horowitz's narratives reveal much about Friedan and feminist movement politics. Contradictions abound. For example, though she dedicates her life to social justice, Friedan is authoritarian and creates organizations that are antidemocratic in structure and political method. Friedan led 
the expulsion of lesbians from NOW and from the movement more generally, and she has been accused of virtually ignoring women who are not white, middle-class, and heterosexual. Her "cultural conservatism," particularly her championing of the conventional family, flies in the face of her own experience with a violent and unhappy marriage, not to mention the testimony — both public and private-from radical and other feminists of the period. Yet these inconsistencies are far more than quirks of Friedan's personality; they demonstrate a number of contradictions and challenges for feminism as a social movement. The criticisms that come from women of color, both academic and activist in orientation, are a case in point. Faulting mainstream feminism for unreflexively setting up white, middle-class, heterosexual women as the norm, feminists of color have argued that both their contributions to feminist theory and action and their lived experiences are often ignored and trivialized. Though Friedan is a very visible example of that tendency, feminism is shaped in significant and multiple ways in the meeting of white privilege with racism and homophobia.

Likewise, Friedan's disagreements and animosities toward other feminists, like Steinem, Ti-Grace Atkinson, Florynce Kennedy, and Bella Abzug, stem from more than personal jealousies. In fact, Friedan had serious doubts about the direction each of these women might take the movement. Hennessee's focus on internal political disagreements, then, strongly suggests that there is no one feminist movement. Rather, a variety of political commitments and organizing strategies, some of which are profiled in Hennessee's book, make up a diverse movement; Friedan's liberal feminism represents just one theoretical and political branch.

That, ultimately, is at least in part Horowitz's point. He argues that secondwave feminism should be understood as emerging from significantly more complex origins than as a "response to the suburban captivity of white middle-class women." Indeed, he copiously documents the impact of "anti-fascism, radicalism, and labor union activism of the 1940s" (7) on Friedan and on the feminist movement. The fact that Friedan ultimately moved away from these commitments does not undermine the argument that both feminist theory and feminism as a social movement were birthed from a complicated — even contradictory — set of political origins and factors. Race and class privilege are but one part of the story; feminism also grew from politically progressive coalitions. One of the most interesting questions that these books leave us with, then, is how these multiple influences might be accounted for today. Horowitz's book makes the point that the politics of race, class, and gender are intricately intertwined. We perhaps understand this better on a theoretical level than in terms of a history of activism. Horowitz's book ultimately challenges its readers to renegotiate their understandings of feminist activism. It shows how important is the historical political intersection of race, class, and gender and opens a dialogue on how they shape current political choices and possibilities for feminism. 